\title{
Implementasi Landasan Filosofis - Teleologis Pendidikan Islam dalam Membangun Pendidikan Karakter (Telaah Surat Ali Imran Ayat 79)
}

\author{
Laelatul Badriah \\ PGMI Universitas Alma Ata \\ email: laelatulbadiah0205@gmail.com
}

\begin{abstract}
Education is a necessity for every human being, education has the task to form the character, both the character of educators and the character of learners. Al Qur'an letter of Imam Ali 79 paragraph emphasizes the formation of rabbani human beings who will form human beings who love science, love to learn and nagging amar ma'ruf nahi munkar. This review is important to provide an overview of the importance of Islamic education in character building. Therefore, this study can provide a new color for the change of paradigm of Islamic education in conducting academic and non academic activities in an effort to form the character from an early age. So that it can reach the rabbani man in accordance with the Qur'an letter of Imran Ali 79 paragraph and can be implemented in the Islamic education practice both formal and non formal.
\end{abstract}

Keyword: character building, insan rabbani, base filosofis - teleologis

\begin{abstract}
Abstrak
Pendidikan merupakan kebutuhan bagi setiap insan, pendidikan memiliki tugas untuk membentuk karakter, baik karekter pendidik maupun karakter peserta didik. surat Ali Imron ayat 79 menekankan pada pembentukan insan rabbani yang akan membentuk insan sebagai manusia yang cinta ilmu, suka belajar dan menegagakkan amar ma'ruf nahi munkar. Kajian ini penting dilakukan untuk memberikan gambaran pentingnya pendidikan islam dalam membangun karakter. Oleh karena itu, kajian ini dapat memberikan warna baru bagi perubahan paradigma pendidikan islam dalam melakukan kegiatan akademik dan non akademik dalam upaya membentuk karakter sejak dini. Sehingga dapat mencapai insan rabbani yang sesuai dengan surat Ali Imran ayat 79 dan dapat diimplementasikan dalam paraktek pendidikan islam baik formal maupun non formal.
\end{abstract}

Kata kunci: Pendidikan Karakter, Insan Rabbani, Landasan Filosofis - Teleologis

\section{PENDAHULUAN}

Proses pendidikan sebenarnya telah berlangsung sepanjang sejarah dan berkembang sejalan dengan perkembangan sosial budaya manusia di permukaan bumi. Sementara itu Allah telah menurunkan petunjuk-petunjuk guna menjaga dan mengarahkan perkembangan sosial budaya tersebut, dengan tidak menyimpang dari tujuan penciptaan alam dan manusia. Petunjuk- petunjuk tersebut disampaikan kepada manusia melalui rasul-rasul Allah, Petunjuk-petunjuk Allah melalui para rasulnya ternyata bukan hanya pengembangan $\mathrm{Al}$ asma $\mathrm{Al}$ husna saja. Tapi juga berkaitan dengan pengembangan $\mathrm{Al}$ asma secara keseluruhan di segala aspek kehidupan manusia yang diciptakan sebagai kholifah Allah.

Pendidikan Islam sebagaimana dilakukan oleh Rasulullah, dimulai dari mengubah 
sikap dan pola fikir masyarakat, menjadikan masyarakat Islam menjadi masyarakat belajar. Berkembang menjadi masyarakat ilmu, yaitu masyarakat yang mau dan mampu menghargai nilai-nilai ilmiah. Masyarakat inilah yang dapat bertanggung jawab untuk mengembangkan ilmu pengetahuan dan teknologi. Orientasi pendidikan Islam harus diletakkan sebagai dasar tumbuhnya kepribadian manusia Indonesia paripurna (insan kamil), sehingga keberadaannya selalu dibutuhkan dan selalu memberikan kontribusi bagi lahirnya masyarakat intelektual.

Dengan demikian, pendidikan memerlukan dan mempunya tujuan yang relevan dan konprehensip bagi kehidupan manusia itu sendiri. Oleh karena itu, pendidikan islam harus memiliki tujuan yang sesuai dengan tujuan dicitkannnya manusia sebagai khalifah di muka bumi ini, sehingga prlu dirumuskan dalam tujuan pendidikan islam yang bersumber kepada al Qur'an secara khusus disebutkan dalam surat surat Ali Imran ayat 79 yakni pendidikan bertujuan membentuk Insan Robbani.

Oleh karena itu, kajian ini peting dengan harapan dapat memberikan kontribusi bagi pendidikan islam dalam menanamkan pendidikan karakter. Insan rabbani dalam pendididikan dapat dilihat dari dua aspek yakni pendidikan dan peserta didik. Pendidik penting memahami insan rabbani sebagai fungsi pokoknya dalam mengemban tugas, demikian pula peserta didik dapat menjadi insan rabbani yang akan membentuknya sebagai manusia yang cinta ilmu, suka belajar dan menegagakkan amar ma'rufnahi munkar sesuai dengan Qur'an surat Ali Imron ayat 79 .

\section{Asbabun Nuzul Surat Ali Imron Ayat 79}

"tidak wajar bagi seseorang manusia yang Allah berikan kepadanya Al Kitab, Hikmah dan kenabian, lalu Dia berkata kepada manusia: "Hendaklah kamu menjadi penyembah-penyembahku bukan penyembah Allah." akan tetapi (dia berkata): "Hendaklah kamu menjadi orang-orang rabbani[208], karena kamu selalu mengajarkan Al kitab dan disebabkan kamu tetap mempelajarinya”
[208] Rabbani ialah orang yang sempurna ilmu dan takwanya kepada Allah s.w.t. ${ }^{1}$

Sekelompok Pemuka agama Yahudi dan Nasrani menemui Rosul saw. Mereka bertanya: "Wahai Muhmmad, apakah engkau ingin kami menyembahmu?" salah satu diantara mereka bernama ar-Rais mempertegas, "apakah untuk itu engkau mengajak kami?" Nabi Muhammad saw menjawab:"Aku berlindung kepada Allah dari penyembahan kepada selain Allah atau menyuruh yang demikian. Allah sama sekali tidak menyuruh aku demikian, tidak pula mengutus aku untuk itu" demikian jawaban Rosul saw. Yang diperkuat dengan turunya ayat ini. ${ }^{2}$

Keterkaitan ayat ini dengan ayat sebelumnya yakni yang dinafikan ayat ini adalah penyembahan kepada selain Allah pada tempatnya karena apaun yang disampaikan oleh seorang nabi atas nama Allah adalah ibadah, baik dalam pengertian yang khusus yakni ibadah murni, mapun dalam pengertian umum yakni segala aktifitas yang dilakukan dengan motivasi mengikuti rosul dan mendekatkan diri kepada Allah. ${ }^{3}$

Dengan demikian, jika memahami asbabun nuzul ayat ini adalah tuntutan bagi umat islam untuk senantiasa menyembah kepada Allah dan buka menyembah kepada nabinya. Akan tetapi ajaran-ajaran yang disampaikan oleh nabi atas nama Allah merupakan suatu ibadah tersendiri jika dilakukan dengan cara baik dan hanya mengharap ridho Allah semata.

\section{Makna Insan Rabbani}

Kata robbani berasal dari rabb yang memiliki aneka makna antara lain pendidik dan pelindung. Dalam kamus Al Munawwir kata rabb memiliki makna memelihara, mengasuh

${ }^{1}$ Departemen Agama RI, Al-'Aliyy Al Qur'an dan Terjemah, (Bandung: Diponogoro; 2000)

${ }^{2}$ M. Quraish Sihab, Tafsir al Misbah Pesan Kesan dan keserasian Al Qur'an, ( Jakarta: Lentera Hati, 2002), juz 3, hlm 159

${ }^{3}$ Ibid, hlm 159 
dan mendidik. ${ }^{4}$ Jika kata ini berdiri sendiri yang dimaksud tidak lain kecuali Allah SWT. Jika dinisbahkan sesuatu biasanya kata ini ditambah dengan huruf ya' seperti kata insan menjadi insan, nur menjadi nuri. Dalam bahasa Indonesia untuk memudahkan mengucapkan terlebih dahulu ditambahkan dengan huruf " $w$ " sehingga misalnya berbunyi manusiawi menjadi nurani dan kata rabb menjadi rabbani sebagaimana bunyi ayat di atas ${ }^{5}$. Arti robbani Ibnu Abbas, Abu Razin dan ulama lainnya yang bukan hanya seorang yang disebut orang-orang yang bijaksana, orang-orang alim bagi orang-orang penyantun. Sedangkan menurut Al- Hasan dan yang lain rabbani disebut orang-orang ahli fiqih, dan menurut Al- Hasan disebutkan pula yang dimaksudkan rabbani adalah ahli ibadah dan ahli takwa ${ }^{6}$

\section{Penjelasan Insan Robbani}

Kata tadrusuun digunakan untuk meneliti sesuatu guna diambil manfaatnya. Dalam konteks teks-teks baik dalam kitab suci maupun selainnya ia adalah membahas dan mendiskusikan teks untuk menarik informasi dan pesan-pesan yang dikandungnya. ${ }^{7}$ Rabbani menurut ayat ini paling tidak melakukan dua hal yaitu ${ }^{8}$ : terus-menerus mengajarkan kitab suci, bahwa seorang rabbani harus terus-menerus mengajar karena manusia tidak pernah luput dari kekurangan dan terus-menerus mempelajarinya, seorang rabbani terus-menerus membahas dan mempelajari kitab suci karena firmanfirman Allah sedemikian luas kandungan dan maknanya, sehingga semakin digali, semakin banyak yang dapat diraih, walaupun yang dibaca adalah teks yang sama. Kitab Allah yang tertulis tidak ubahnya dengan kitab-Nya yang terhampar, yaitu alam raya.

\footnotetext{
${ }^{4}$ Ahmad Warson Munawwir, Kamus Al munawwir Arab-Indonesia Terlengkap, (Surabaya: Pustaka Progresif, 1997) hlm. 462

${ }^{5}$ M. Quraish Sihab, Tafsir al Misbah Pesan Kesan dan keserasian Al Qur'an... hlm, 160

${ }^{6}$ Al Imam Abul Fida Ismalil Ibnu Katsir Ad Dimasyiqi Tafsir Ibnu Katsir Juz 3 surat Al Baqoroh ayat 253 s.d. Ali Imron ayat 91 Sinar Baru Alge Sindo

${ }^{7}$ Ibid hlm. 161

${ }^{8}$ Ibid hlm 161
}

Jika dengan demikian seseorang Robbani tidak boleh berhenti mempelajari kitab Allah, meneliti, dan membahas baik objeknya alam raya maupun kitab suci. Hal ini sesuai dengan pesan agama bahwa "Belajarlah dari buaian hingga liang lahat" yang berarti belajarlah dari sejak dalam kandungan seorang ibu sampai pada liang lahat yang dimaksud adalah sampai orang itu meninggal dunia.

Rabbani ialah orang yang sempurna ilmu dan takwanya kepada Allah SWT. Menurut salah seorang ulama tafsir, yakni Imam Atthabari, orang-orang Rabbani memiliki karakter sebagai berikut: ${ }^{9}$ Pertama Faqih, Faqih adalah memiliki pemahaman islam yang baik. Memahami prinsip-prinsip dasar islam seperti aqidah, ibadah, akhlak dan muamalah; Kedua 'Alim, Orang yang 'alim adalah orang yang berilmu. Secara umum ilmu Allah terbagi dua cabang yaitu ilmu yang khusus dan ilmu yang umum. Ilmu yang khusus melalui jalur wahyu Allah, sementara ilmu yang umum Allah ilhamkan dan dengan kemampuan manusia ilmu tersebut dapat dirumuskan. Oleh karena itu, definisi ilmu dalam konteks ini adalah spesialisasi atau keahlian. Misal dengan ilmu fisiologi, anatomi, patologi, seseorang dapat dikatakan dokter; Ketiga "Melek" Politik, Artinya orang yang rabbani peka terhadap kondisi rakyat dan negaranya. Mereka (generasi rabbani) tidak hanya faqih dan 'alim namun juga memiliki kesadaran berpolitik yang baik. Sehinga dapat dikatakan mereka benar-benar peduli dan kontributif terhadap bangsanya; Empat "Melek" Manajemen, Generasi rabbani teratur dalam segala urusannya. Karena memahami ilmu manajemen dan senantiasa mengamalkannya; dan Lima mampu menjalankan urusan orang lain dengan baik, atau dalam istilah lain memiliki sifat amanah dan cakap menjalankan pekerjaannya (amanah tersebut).

As-Syahid Sayyid Quthb dalam rumusannya mengenai generasi Rabbani (dengan merujuk pada generai sahabat era

${ }^{9}$ Firmansyah Rowardi konsep insan kamil dalam perspektif pendidikan islam korelasinya 
Rasulullah SAW), mengemukakan tiga ciri penting dari generasi awal islam itu, seperti: selalu membersihkan dari dari segala unsur jahiliyah, sumber rujukan mereka yang utama hanyalah Al-Qur'an al Karim, dan apa yang dipelajarai semata-mata hanyalah untuk diamalkan. Kelahiran generasi rabbani menjadi mungkin, jika umat tetap berpegang pada Al-Qur'an dan Al-Hadits. Diperlukan pula banyaknya murabi yang mempunyai keluasan dan kedalaman ilmu. Disamping itu, generasi rabbani akan terlahir jika banyak keluarga telah mencapai derajat sakinah, institusi pendidikan, masyarakat serta negara berkomitmen penuh atas tegaknya dakwah islamiyah. Usaha melahirkan kembali generasi rabbani di akhir zaman, merupakan ikhtiar suci yang memerlukan pengorbanan diri, waktu dan harta. Allah berfirman dalam surat Al-Maidah ayat 54 , yang artinya:

54. Hai orang-orang yang beriman, Barangsiapa di antara kamu yang murtad dari agamanya, Maka kelak Allah akan mendatangkan suatu kaum yang Allah mencintai mereka dan merekapun mencintaiNya, yang bersikap lemah lembut terhadap orang yang mukmin, yang bersikap keras terhadap orangorang kafir, yang berjihad dijalan Allah, dan yang tidak takut kepada celaan orang yang suka mencela. Itulah karunia Allah, diberikanNya kepada siapa yang dikehendaki-Nya, dan Allah Maha Luas (pemberian-Nya), lagi Maha mengetahui.

Di dalam sebuah hadits Nabi disebutkan:

$$
\begin{aligned}
& \text { و قال النبي ص : من يرد الله به خيرا يفقهه و إنما العلم } \\
& \text { بالتعلّم و و قال ابن عباس : كونوا ربّانيّين حلماء فقهاء } \\
& \text { • و يقال : الربّاني الّذي يربّي الناس بصغار العلم قبل }
\end{aligned}
$$

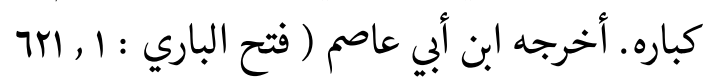

“Nabi bersabda, siapa yang dikehendaki Allah pada kebaikan, Ia menjadikannya Faqih (faham), dan hanyalah ilmu itu (diperoleh) dengan belajar. Ibnu Abbas berkata, jadilah kamu orang Rabbani yang sabar murah hati dan yang faqih. Dan dikatakan Rabbani itu yang suka mendidik manusia mulai dari yang kecil lalu pada yang besar. Dikeluarkan oleh Ibnu Abi Ashim.” (Fath al-Bari: I,162)

Secara konteks hadits di atas berkenaan dengan perintah menjadi Insan Rabbani, Insan rabbani di sini ialah orang yang mendidik manusia, memberi pelajaran pada mereka dengan ilmu pengetahuan, mulai dari masalah yang kecil / mudah difahami kemudian berpindah kepada masalah yang besar yang sulit dipahami.

Dengan memperhatikan penjelasan di atas, maka dapat dikatakan Rabbani dalam Ali Imran 79, antara lain dimaksudkan, orang yang membaca, mempelajari kitab dengan memahami

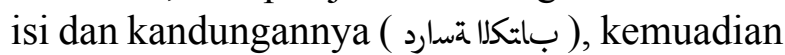
mengamlakannaya, serta mengajarkannya kepada manusia (بلماتئ) dengan metode induktif/mulai dari yang kecil kemudian pada yang besar, selanjutnya ia akan menjadi pendidik. dengan demikian dari ayat diatas tersirat insan rabbani mempuyai peran untuk menyiapkan generasi lanjut yang siap dan selalu belajar dan haus ilmu pengetahuan, sehingga akan menjadi seorang pengajar yang kemuadian akan menjadi pendidik. dengan demikian dapata digaris bawahi insan Rabbani itu adalah sesorang yang be iman dan bertakwa, menjalankan dan menjaga ketuhanannya dengan selalu melakukan amar ma'ruf nahi munkar. yang kemudian akan mengajarkannya kepada orang lain serta mendidiknya.

Demikian insan rabbani dalam membentuk tujuan pendidikan islam memiliki yang luas dalam memaknai kehidupan. Kualitas rabbani dalam kontek tujuan pendidikan dalam membentuk peserta didik yaitu rabbani sebagai orang yang sempurna ilmu, sempurna, takwa, sempurna imanya. Dan sebagai manusia yang mirip tuhan, meniru tuhan, dan meyakini hidupnya untuk mengabdi kepada tuhan, sehingga dengan ada karakteristik insan rabbani tersebut diharapkan dapat membentuk pribadi peserta didik yang taat yang disertai ketundukan yang mengandung makna pengabdian diri 
kepada tuhan dan memperhatikan rambu-rambu yang harus dihindari dalam kehidupan sehingga dapat memaknai kehidupan secara khidmat.

\section{Implementasi Landasan Filosfis-Teleologis dalam Pendidikan Islam Berdasarkan Surat Ali Imron Ayat 79}

Inti dari kandungan surat Ali Imran ayat 79 dalam konsep pendidikan yang mempunyai arti penting dalam tujuan pendidikan islam yaitu pendidkan untuk mengantarkan peserta didik memuliakan kehidupan dan untuk mengembangakan hidup bermakna. Berkaitan kata insan robbani dalam tafsir ibnu katsir dapat ditarik dua kata pembelajar dan pengajar. Maka dalam kotek pembelajaran pendidikan agama islam terdapat dua komponen pembelajaran penting yakni peserta didik dan pendidik. Oleh karena itu, kedua unsur ini saling berkaitan dan harus terus menerus menggali ilmu Allah dengan harapan semakin banyak yang dicari dari ilmu Allah maka akan semakin baik dari tujuan pendidikan yang akan dihasilkaan dari pendidik serta akan menciptakan para peserta didik yang berkompetensi dalam bidangnya masingmasing dengan harapan mampu mengantarkkan peserta didik untuk mengamalkan ajaran agama dalam kehidupan menjadi lebih bermakna.

Dengan demikian dari surat Ali Imron ayat 79 di atas, membutuhkan pendidik dan peserta didik yang mampu mengamalkan ajaran agama islam dengan cara memperbaiki kualitas komponen pendidikan islam terutama pendidik dan peserta didik untuk mencapai tujuan pendidikan secara maksimal sehingga dapat mengantarkan peserta didik yang mampu mengembangkan hidup secara bermakna dengan cara beriman, beramal soleh, dan mengabdikan diri kepada Allha swt.

\section{Pendidik}

Istilah pendidik dalam bahasa Arab biasa dipakai kata al-Murabbi atau kadang-kadang juga dipakai kata al-Mu'addib (pendidik khusus), sedangkan untuk istilah guru dalam bahasa Arab biasa dipakai kata al-Mu'allim atau al-Mudarris. Pendidik adalah salah satu faktor dalam proses pendidikan yang memegang peranan penting. Pendidik atau guru inilah yang bertanggungjawab dalam pengoperan nila-nilai yang telah ditetapkan oleh lembaga pendidikan untuk dimiliki oleh para pendidik. Keberhasilan aktifitas pendidikan banyak bergantung pada keberhasilan para pendidiknya dalam mengemban misi kependidikannya. ${ }^{10}$ Itulah sebabnya Islam sangat menghormati dan menghargai orang-orang yang mau bertugas sebagai guru atau pendidik. Nabi SAW bersabda:

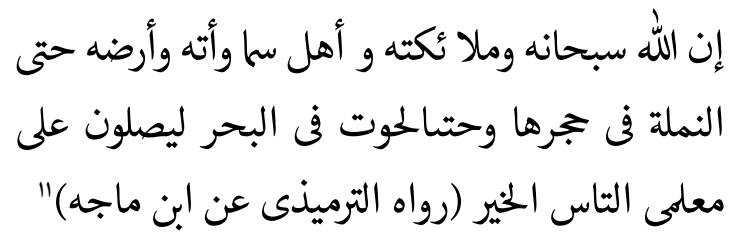

Seperti yang dikatakan oleh M. Tolchah Mansur dalam kitabnya Ta'lim al-Muta'allim yang termasuk arti mengagungkan ilmu, yaitu

$$
\text { وأعن تعظيم العلم تعظيم المعلم, قال علي- كرّم الله وجهـ }
$$

Pekerjaan sebagai seorang guru adalah pekerjaan yang luhur dan mulia, baik ditinjau dari sudut masyarakat dan negara maupun ditinjau dari sudut keagamaan. Guru sebagai pendidik adalah seseorang yang berjasa besar terhadap masyarakat dan negara. ${ }^{13}$

Oleh karena itu, sebagai pelajar hendaknya menghormati dan mencintainya sebagaimana kita mencintai ayah dan ibu kita. Umar Ibnu Ahmad Baradja mengemukakan dalam kitabnya al-Akhlak li al-Banaat:

${ }^{10} \mathrm{H}$. Abu Tauhid MA. Beberapa Aspek Pendidikan Islam, ( Yogyakarta: Sekretariat Ketua Jurusan Fak. Tarbiyah IAIN Sunan Kalijaga), hlm. 39

${ }^{11}$ Sunan at-Turmudzi, No. 2685, Juz. 5, hlm. 50

${ }^{12}$ M.Tolchah Mansur, Bimbingan bagi Penuntut Ilmu Pengetahuan (Ta'limu al-Muta'alim), Terj. H. Aly As'ad, (Kudus: Menara Kudus, 1978), hlm. 22

${ }^{13}$ M. Ngalim Purwanto, Ilmu Pendidikan Teoritis dan Praktis,( Bandung: Rosda Karya, 2002), hlm. 138 


$$
\begin{aligned}
& \text { إنّك تحبّين والديك :لأنّهما يربّيانك في البيت, فأحبّى }
\end{aligned}
$$

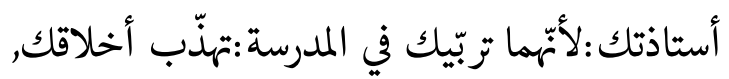

$$
\begin{aligned}
& \text { وتعامك العلم الذى ينفعك, وتنصحك مفيدة. }
\end{aligned}
$$

Seperti dalam kitab Taisiru al-Khalaak ditegaskan bahwa: Guru adalah seseorang yang menunjukkan kesempurnaan ilmunya dan mengerti serta memberi pengertian kepada murid. Maka seorang guru harus mempunyai sifat-sifat terpuji, karena jiwa seorang murid itu lebih rendah dari pada guru yang telah memiliki sifat-sifat yang sempurna. Sebab murid pasti akan meniru atau mencontoh kelakuan guru tersebut. Diantara sifat-sifat terpuji yang harus dimiliki oleh seorang guru adalah takwa, tawadu', sabar, memberi nasehat, berkata baik, dan kasih sayang, semua itu supaya murid bisa meniru dan mendapatkan hasil yang baik dan supaya seorang guru tidak membebankan kepada murid yang tidak mungkin diselesaikan. ${ }^{15}$

\section{Syarat-syarat menjadi guru yang baik.}

Dari uraian di atas, jelaslah bahwa pekerjaan seorang guru itu berat tetapi luhur dan mulia. Maka, sebagai guru yang baik harus memenuhi syarat-syarat yang ada. Para ahli pendidikan Islam banyak merumuskan sifatsifat atau syarat-syarat yang harus dimiliki oleh setiap pendidik muslim, diantara para ahli tersebut adalah Imam Al-Ghazali, Athiya al-Abrasy, An-Nahlawi, dan lain-lain, dari berbagai pendapat para ahli tersebut Abu Tauhid merumuskan bahwa seorang pendidik atau guru itu harus memiliki: ${ }^{16}$ memiliki sifat Rabbani, memiliki sifat ikhlas, memiliki sifat zuhud, memiliki sifat jujur dan konsekuen, memiliki sifat sabar dan tabah hati, memiliki sifat penyantun dan pemaaf, memiliki sifat keteladanan, memiliki sifat adil, memiliki sifat kebapakan atau keibuan, mengetahui

\footnotetext{
${ }^{14} \mathrm{Al}-U s t a d z$ Umar Bradja, al-Akhlak li al- Banaat, (Surabaya: 1359 H ), hlm. 35

${ }^{15}$ Hafid Hasan Mas'ud, Taisiru al-Khalaaq, Terj. Ahmad Aukarto Rembang (Surabaya), hlm. 6

${ }^{16}$ H. Abu Tauhid MA. Beberapa Aspek Pendidikan Islam, hlm. 45-56
}

dan memahami tabiat peserta didik, dan menguasai bidang studinya dan seruis terusmenerus meningkatkan pengetahuannya. Sebagaimana ditambahkan M. Ngalim Purwanto menyimpulkan bahwa syarat-syarat untuk menjadi guru yang baik adalah berijazah, sehat jasmani dan rohani, takwa kepada Allah dan berkelakuan baik, bertanggung jawab, dan berjiwa nasional. ${ }^{17}$

\section{Tugas pendidik atau guru}

Menurut Muhammad Syakir, pendidik adalah sebagai seorang yang menjadi suritauladan, penasehat, dan pentunjuk arah bagi pendewasaan peserta didiknya dalam setiap gerak-geriknya. Oleh karena itu, seorang guru atau orang alim akan dipantau oleh setiap orang atau lebih khusus lagi adalah anak didiknya. Sebagai mana uangkapannya yang berbunyi:

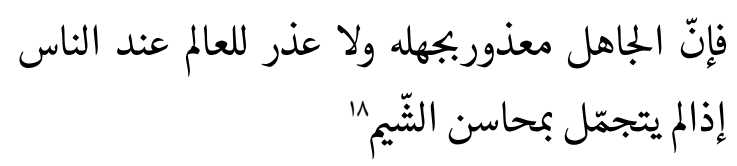

Dari sini Muhammad Syakir memberikan rambu-rambu yang harus ditaati bagi seorang pendidik atau orang alim yaitu harus memiliki watak yang baik dan terwujud dengan baik akhlaknya.

Seorang guru yang diberi kepercayaan penuh untuk mengarahkan dan membimbing anak didiknya dalam proses belajar mengajar. Menurutnya seorang pendidik berhak memerintahkan, memberi tugas yang dapat menunjang demi tercapainya tujuan proses belajar mengajar yang akan dicapai, yaitu penerapan akhlak karimah dalam kehidupan sehari-hari bagi peserta didik.

Guru sebagai warathatul anbiya' mempunyai fungsi untuk menjadi manager of learning (pengelolah), director of learning (pengarah belajar), fasilitator, dan the planner of fiture society. Sehingga perannya guru harus mampu menjadi pemimimpin, pembimbing,

${ }^{17}$ M. Ngalim Purwanto, Ilmu Pendidikan Teoritis dan Praktis, hlm. 139

${ }^{18}$ Muhammad Syakir, Washoya Al-Abaa' li alAbnaa', hlm. 4

LITERASI, Volume VIII, No. 2 2017 | 133 
pengawas, pendamping di dalam mempelajari dan mencoba sesuatu bahan yang diperlukan untuk memenuhi kebutuhan hidupnya, baik dalam proses pendidikan yang berlangsung maupun untuk masa yang akan datang. ${ }^{19}$

\section{Peseta didik}

Peserta didik memiliki persamaan kata anak didik, siwa, dan murid. Istilah anak didik dalam bahasa Arab biasa dipakai kata الطفل dan sedangkan untuk istilah peserta didik atau pelajar biasa dipakai istilah "المتعلم, التميذ, الطالب. Adanya berbagai istilah itu, pada hakikatnya tidak mengandung perbedan-perbedaan yang prinsip, sehingga bisa dipakai salah satunya dari istilah tersebut, ataupun dipergunakan secara bersama-sama atau bergantian.

Anak didik adalah setiap orang yang menerima pengaruh dari seseorang atau sekelompok orang yang menjalankan kegiatan pendidikan ${ }^{21}$ peserta didik adalah anak didik yang sedang tumbuh dan berkembang baik secara fisik mapun psikologis untuk mencapai tujuan pendidikannya melalui lembaga pendidikannya. Peserta didik merupakan orang yang belum dewasa dan memiliki sejumlah potensi (kemampuan) dasar yang masih perlu dikembangkan. ${ }^{22}$

Dari dua pengertian di atas bahwa peserta didik merupakan subjek dan objek pendidikan yang memerlukan bimbingan, didikan, dan motivasi untuk dapat mengembangkan dirinya untuk menemukan potensi yang ada dalam peserta didik untuk mencapai manusia yang berakhlakul karima sesuai dengan ajaran agama islam. Oleh karena itu, dalam kotentek pendidikan dalam proses pembelajaran tidak akan bejalan dengan baik jika peserta didik tidak

${ }^{19}$ Departemen Agama RI, Islam untuk Disiplin Ilmu Pendidikan, (Jakarta: Direktorat Jenderal Pembinaan Kelembegaan gama Islam, 1997), hlm. 167

${ }^{20} \mathrm{Ahmad}$ Warson Munawwir, Kamus Al munawwir Arab-Indonesia. ., hlm. 859,

${ }^{21}$ Saful Bahri Djamaroh, Guru dan anak didik dalam interaksi edukatif suatu pendekatan teoritis edukatif, (Jakarta; Rineka Cipta, 2005), hlm;51

${ }^{22}$ Arifudin Arif, Pengatar Ilmu Pendidikan Islam (Jakarta, kultura pres; 2008), hlm. 71 ada, maka pendidik seharusnya mengetahui hakekat peserta didik itu sendiri. Siswa atau peserta didik adalah satu-satunya komponen manusia yang mempunyai posisi sentral dalam proses belajar-mengajar, dalam proses belajar-mengajar siswa sebagai yang meraih cita-cita, memiliki tujuan, dan kemudian ingin mencapainya secara optimal.

Beberapa hakekat peserta didik dalam pendidikan agama islam ${ }^{23}$ yaitu: pertama peserta didik bukan merupakan miniatur orang dewasa, akan tetapi memiliki dunianya sendiri, dua peserta didik adalah yang memiliki deferensi priodisasi perkembnagan dan pertumbuhan, tiga peserta didik adalah manusia yang memiliki kebutuhan, baik yang menyangkut kebutuhan jasmani maupun rohani yang harus dipenuhi, peserta didik adalah akhluk Allah yang memiliki perbedaan individual (diferensiasi individual) baik disebabkan pembawaan maupun lingkungan dimana ia tinggal, peserta didik merupakan resultan dari dua unsur utama yaitu unsur jasmani dan rohani, peserta didik adalah manusia yang memiliki potensi (firah) yang dapat dikembangkan dan berkembang secara dinamis.

Sebagai manusia peserta didik memiliki karakteristik tersendiri menurut Sutari Imam Barnadib, Sowarno, dan Siti Machati yang dikutip Saiful Bahri Djamaroh sebagai berikut; ${ }^{24}$ belum memiliki pribadi dewasa sehingga masih menjadi tanggung jawab pendidik, masih menyempurnakan aspek kedewasaan sehingga masih menjadi tanggung jawab pendidik, dan memiliki sifat-sifat dasar manusia yang sedang berkembang secara terpadu yaitu kebutuhan biologis, rohani, sosial, intelegensi, seta perbedaan individu.

Secara qodrati anak memerlukan bimbingan dan pendidikan dari orang dewasa. ${ }^{25}$ Anak didik didalam mencari nilai-nilai dalam

\footnotetext{
${ }^{23}$ Ibid. hlm. 72-74

${ }^{24}$ Saful Bahri Djamaroh, Guru dan anak didik dalam interaksi edukatif hlm.52

${ }^{25}$ M.Athiya al-Abrasyi, Dasar-dasar Pokok Pendidikan Islam ( Attarbiyah al-Islamiyah), Terj. Bustami Again dan Djohar Baheny L.I.S., (Jakarta: Bulan Bintang, 1970), hlm. 113
} 
hidupnya harus dapat bimbingan sepenuhnya dari pendidiknya. Karena menurut agama Islam anak lahir dalam keadaan suci atau fitrah dan lemah, sedangkan alam sekitarnyalah yang memberikan corak dalam kehidupannya. ${ }^{26} \mathrm{Hal}$ ini ditegaskan dengan sabda Nabi SAW:

$$
\begin{aligned}
& \text { مامن مولود إلا يولد على الفطرة فأبوه يهودانه أوينصرانه }
\end{aligned}
$$

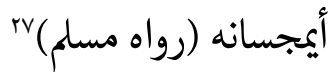

Firman Allah SWT:

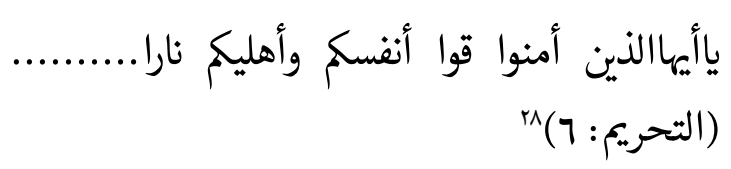

Maka berdasarkan ayat di atas orang tua menempati wewenang yang tertinggi dan mengemban tanggung jawab yang berat terhadap pelaksanaan pendidikan anak-anaknya. ${ }^{29}$

Muhammad Syakir mengaggap bahwa seorang peserta didik adalah anak kecil yang tersesat jika tidak menaati dengan apa saja yang diperintahkan oleh gurunya. Karena peserta didik hanyalah seorang anak kecil yang belum dewasa secara jasmani dan rohani dan kebaikannya tergantung pada apapun yang akan diarahkan oleh seorang guru. Hal ini diakui oleh aliran empirisme bahwa pengaruh faktor-faktor dari luar (lingkungan) saja yang berpengaruh pada perkembangan dan pertumbuhan anak, sedangkan faktor dari dalam yang bersifat kodrati dianggap tidak berpengaruh terhadapnya. ${ }^{30}$ Beliau menekankan bahwa interaksi antara pendidik dan peserta didik harus selalu dilandasi rasa cinta dan kasih sayang. Hal ini tercermin dalam kitabnya yang pada setiap baitnya menggunakan kalimat ya bunayya yang berarti wahai anak laki-laki kecilku.

Begitu pula al-Ghazali dalam kitabnya Ihya Ulumuddin mengungkapkan bahwa anakanak adalah amanah di tangan ibu-bapaknya,

\footnotetext{
${ }^{26}$ Zuhairini, dkk. Filsafat Pendidikan Islam, (Jakarta: Bumi Aksara, 2004), hlm.170

${ }^{27}$ Shohih Bukhori, No. 1293, Juz. 1 hlm. 456

${ }^{28}$ al-Qur'an dan Terjemah, ( Bandung: Diponegoro, 2003 ), hlm. 448

${ }^{29} \mathrm{Abu}$ Tauhid, Beberapa Aspek Pendidikan Islam, .....hlm. 58

${ }^{30}$ Ibid, hlm. 127
}

hatinya masih suci ibarat permata yang mahal harganya. ${ }^{31}$ Dalam hal ini seorang peserta didik dijadikan sebagai objek dari pendidikan, namun pada kenyataannya, penempatan peserta didik selain sebagai objek didik juga sebagai subjek didik adalah wajib bagi seorang pendidik yang baik.

\section{Tata krama peserta didik terhadap guru}

Hafidz Hasan Mas'udi dalam kitabnya Taisiru al-Khalak mengemukakan adab seorang peserta didik kepada gurunya, yaitu

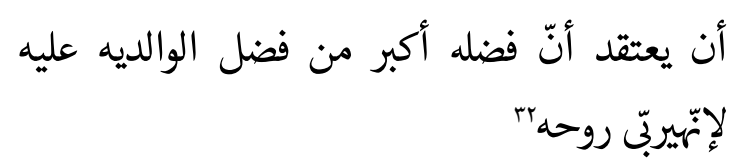

Maka dari ungkapan di atas, tata krama peserta didik kepada gurunya adalah: rendah hati, duduk ketika pelajaran, tidak bermainmain (senda gurau) dan tidak memuji ulama yang lain kecuali gurunya didepannya. Karena sesungguhnya guru paham bahwa itu merupakan suatu penghinaan terhadap dirinya, dan peserta didik tidak malu terhadap apa yang tidak diketahuinya dari soal. ${ }^{33}$

\section{Kewajiban-kewajiban peserta didik dalam pendidikan Islam}

Peserta didik memiliki kewajiba-kewajiban yang harus dikerja oleh masing -masing pribadi peserta didik diantaranya: pertama sebelum belajar, peserta didik harus membersihkan hatinya dari segala sifat buruk, karena belajar dan mengajar merupakan ibadah, kedua dengan belajar, ia dimaksudkan untuk mengisi jiwanya dengan fadilah dan mendekatkan diri kepada Allah, tiga bersedia mencari ilmu, termasuk untuk meninggalkan keluarga demi untuk mendatangi gurunya, Emapat Harus tetap taat pada guru yang mengajarnya, lima menghormati guru dan memulyakannya serta mengagungkannya karena Allah, enam idak hlm. 114

${ }^{31}$ M. Athiya al-Abrasyi, Attarbiyah al-Islamiyah,

${ }^{32}$ Hafidz Hasan Mas'ud, Taisiru al-Khalaak, (Semarang: Toha Putra), hlm. 5

${ }^{33}$ Ibid, hlm. 8 
membuka rahasia kepada guru dan tidak menipunya, tujuhi bersungguh-sungguh dan tekun belajar dan mengulangi kembali, delapan saling mencintai dan menghargai persaudaraan yang telah terjalin, Sembilan siswa harus memberi salam kepada gurunya, dsan sepuluh bertekad untuk mencari ilmu sampai akhir umur dan tidak meremehkan ilmu. ${ }^{34}$

\section{KESIMPULAN}

Berdasarkan pembahasan dalam surat Ali Imran ayat 79 , implementasi pada pendidikan islam terdapat dua komponen penting dalam melaksanakan peoses pembelajaran yakni pendidik dan peserta didik. Dimana dari kedua komponen itu harus memenuhi syarat dan kriteria untuk mencapai tujuan pembelajaran guna mencetak peserta didik yang mampu mengembangkan hidup yang lebih bermakna, mampu mengamalkan ilmunya, dan mampu menjadi hammba Allah yang taat.

Pendidik dalam pembahasan ini yang terus menerus mengajarkan ilmunya kepada peserta didik, peserta didik yang terus menerus untuk belajar dan menggali ilmu pengetahuan, yang haus akan ilmu untuk mengembangkan hidup untuk mengabdi kepada Allah, serta materimateri pelajaran yang sesuai dengan amal soleh untuk mencapaik kehidupan yang lebih baik. Dengan demikian diharapkan mampu mencapai tujuan pembelajaran sesuai dengan kompetensi yang ditetapkan masing-masing lembaga pendidikan.

\section{DAFAR PUSTAKA}

Departemen Agama RI, 2000, Al-'Aliyy Al Qur'an dan Terjemah, Bandung: Diponogoro Quraish Sihab, 2002, Tafsir al Misbah Pesan Kesan dan keserasian Al Qur'an, Jakarta: Lentera Hati, Juz 3 , 2002, Tafsir al Misbah Pesan Kesan dan keserasian Al Qur'an, Jakarta: Lentera Hati, 2002), juz 6 hlm. 121

${ }^{34}$ M. Athiya al-Abrasyi, Attarbiyah al-Islamiyah, 136 LITERASI, Volume VIII, No. 22017
Ahmad Warson Munawwir, 1997, Kamus Al munawwir Arab-Indonesia Terlengkap, Surabaya: Pustaka Progresif

Al Imam Abul Fida Ismalil Ibnu Katsir Ad Dimasyiqi Tafsir Ibnu Katsir Juz 3 surat Al Baqoroh ayat 253 s.d. Ali Imron ayat 91 Sinar Baru Alge Sindo

Tafsir Ibnu Katsir Juz 14 surat An-Nahl Sinar Baru Alge Sindo

H. Abu Tauhid MA. Beberapa Aspek Pendidikan Islam, Yogyakarta: Sekretariat Ketua Jurusan Fak. Tarbiyah IAIN Sunan Kalijaga Sunan at-Turmudzi, No. 2685, Juz. 5, hlm. 50 M.Tolchah Mansur, 1978, Bimbingan bagi Penuntut Ilmu Pengetahuan (Ta'limu alMuta'alim), Terj. H. Aly As'ad, Kudus: Menara Kudus.

M. Ngalim Purwanto, 2002, Ilmu Pendidikan Teoritis dan Praktis, Bandung: Rosda Karya Al-Ustadz Umar Bradja, 1359H, al-Akhlak li al- Banaat, Surabaya

Muhammad Syakir, Nasehat Ayah kepada Anaknya agar menjadi Manusia Berakhlak Mulia,terj. H.M.Fadlil Sa'id An-Nadwi, ( Surabaya: Al-Hidayah) hlm.11-13

Hafid Hasan Mas'ud, Taisiru al-Khalaaq, Terj. Ahmad Aukarto Rembang Surabaya

Departemen Agama RI, 1997, Islam untuk Disiplin Ilmu Pendidikan, Jakarta: Direktorat Jenderal Pembinaan Kelembegaan gama Islam

Saful Bahri Djamaroh, 2005, Guru dan anak didik dalam interaksi edukatif suatu pendekatan teoritis edukatif, Jakarta ; Rineka Cipta.

Arifudin Arif, 2008, Pengatar Ilmu Pendidikan Islam, Jakarta, Kultura Pres

M.Athiya al-Abrasyi, 1970, Dasar-dasar Pokok Pendidikan Islam (Attarbiyah al-Islamiyah), Terj. Bustami Again dan Djohar Baheny L.I.S., Jakarta: Bulan Bintang

Zuhairini, dkk. 2004, Filsafat Pendidikan Islam, Jakarta: Bumi Aksara.

Shohih Bukhori, No. 1293, Juz. 1

al-Qur'an dan Terjemah, Bandung: Diponegoro, Hafidz Hasan Mas'ud, Taisiru al-Khalaak, Semarang: Toha Putra 
Quraish Sihab, 2002, Tafsir al Misbah Pesan Kesan dan keserasian Al Qur'an Juz 6, Jakarta: Lentera Hati

Oli Abdul Rohman dan M Khomzah, 2009, Menjaga Akidah Dan Akhlak, Tiga Serangkai, Solo
Abu Aya, Kehidupan Yang Baik Menurut AlQur`An TTP://AQLISLAMICCENTER. COM/2014/09/18/KEHIDUPAN-YANGBAIK-MENURUT-AL-QURAN/ 